\title{
EARLY CHANGES IN SOIL METABOLIC DIVERSITY AND BACTERIAL COMMUNITY STRUCTURE IN SUGARCANE UNDER TWO HARVEST MANAGEMENT SYSTEMS
}

\author{
Lucas Carvalho Basilio Azevedo ${ }^{(1) *}$, Marcio Morais $^{(2)}$ and Marcio Rodrigues Lambais ${ }^{(2)}$ \\ (1) Universidade Federal de Uberlândia, Instituto de Ciências Agrárias, Uberlândia, Minas Gerais, Brasil. \\ (2) Universidade de São Paulo, Escola Superior de Agricultura "Luiz de Queiroz", Departamento de Ciência do Solo, Piracicaba, São \\ Paulo, Brasil. \\ * Corresponding author. \\ E-mail: lcbazevedo@iciag.ufu.br
}

\begin{abstract}
Preharvest burning is widely used in Brazil for sugarcane cropping. However, due to environmental restrictions, harvest without burning is becoming the predominant option. Consequently, changes in the microbial community are expected from crop residue accumulation on the soil surface, as well as alterations in soil metabolic diversity as of the first harvest. Because biological properties respond quickly and can be used to monitor environmental changes, we evaluated soil metabolic diversity and bacterial community structure after the first harvest under sugarcane management without burning compared to management with preharvest burning. Soil samples were collected under three sugarcane varieties (SP813250, SP801842 and RB72454) and two harvest management systems (without and with preharvest burning). Microbial biomass C (MBC), carbon (C) substrate utilization profiles, bacterial community structure (based on profiles of 16S rRNA gene amplicons), and soil chemical properties were determined. MBC was not different among the treatments. C-substrate utilization and metabolic diversity were lower in soil without burning, except for the evenness index of C-substrate utilization. Soil samples under the variety SP801842 showed the greatest changes in substrate utilization and metabolic diversity, but showed no differences in bacterial community structure, regardless of the harvest management system. In conclusion, combined analysis of soil chemical and microbiological data can detect early changes in microbial metabolic capacity and diversity, with lower values in management without burning. However, after the first harvest, there were no changes in the soil bacterial community structure detected by PCR-DGGE under the sugarcane variety
\end{abstract}


SP801842. Therefore, the metabolic profile is a more sensitive indicator of early changes in the soil microbial community caused by the harvest management system.

Keywords: 16S rRNA gene, harvest management, metabolic profile, microbial activity, PCR-DGGE.

\author{
RESUMO: MUDANÇAS INICIAIS NA DIVERSIDADE METABÓLICA E NA ESTRUTURA \\ DA COMUNIDADE BACTERIANA DO SOLO EM CANA-DE-AÇÚCAR, EMDOIS \\ SISTEMAS DE MANEJO DE COLHEITA
}

\begin{abstract}
A queima da cana-de-açúcar previamente à colheita é amplamente utilizada no Brasil. Entretanto, em razão das restrições ambientais, a colheita sem queima vem ganhando espaço. Consequentemente, espera-se que o acúmulo de resíduos da cultura na superfície do solo altere a comunidade microbiana, iniciando mudanças na diversidade metabólica do solo desde a primeira colheita. Uma vez que os atributos biológicos respondem rapidamente e podem ser úteis para o monitoramento de mudanças ambientais, o objetivo deste trabalho foi avaliar as mudanças iniciais na diversidade metabólica do solo e na estrutura da comunidade bacteriana com a eliminação da queima, quando comparada ao manejo com queima prévia à colheita da cana-de-açúcar. Amostras de solo foram coletadas sob as variedades de cana-de-açúcar SP813250, SP801842 e RB72454, colhidas sem a queima e com queima prévia. O carbono da biomassa microbiana (MBC), os perfis de utilização de substratos de $C$, a estrutura da comunidade bacteriana com base nos perfis de amplicos do gene 16S rRNA e as propriedades químicas do solo foram determinados. $O M B C$ não se diferenciou entre os tratamentos. A utilização de substratos de C e a diversidade metabólica foram menores no solo sem queima, exceto para o indice de equitabilidade de uso dos substratos. As amostras de solo sob a variedade SP801842 apresentaram as maiores mudanças na utilização de substratos e na diversidade metabólica, mas não diferiram na estrutura da comunidade bacteriana, independentemente do sistema de manejo de colheita. Em conclusão, a análise conjunta de dados químicos e microbiológicos do solo permite detectar alterações iniciais na capacidade e diversidade metabólica microbiana, com menores valores no manejo sem queima. Entretanto, após a primeira colheita, não houve mudanças na estrutura da comunidade bacteriana do solo detectada por PCR-DGGE sob a variedade SP801842. Portanto, o perfil metabólico é o indicador mais sensível para mudanças iniciais na comunidade microbiana do solo, causadas pelo sistema de manejo de colheita.
\end{abstract}

Palauras-chave: manejo de colheita, gene 16S rRNA, perfil metabólico, atividade microbiana, PCR-DGGE.

\section{INTRODUCTION}

Brazil is one of the main world producers of sugar and ethanol derived from sugarcane, with an estimated area of 9.1 million ha of cropped sugarcane, and an estimated production of 672 megatons in the 2014/2015 crop year (Conab, 2014).

Most sugarcane cropping in Brazil is performed through use of preharvest burning in order to facilitate manual cutting. However, in addition to emission of greenhouse gases (IPCC, 1995), periodic burning interferes in the ecosystems surrounding sugarcane cropping areas, pollutes the air (Mieville et al., 2010), and damages human health in rural areas and nearby urban centers (Cançado et al., 2006).

In management systems without preharvest burning, part of the $\mathrm{C}$ from crop residues is stored in the soil, increasing organic matter and reducing $\mathrm{CO}_{2}$ emissions to the atmosphere (Galdos et al., 2009, 2010; Machado et al., 2010). In addition to increasing $\mathrm{C}$ stocks, the accumulation of soil organic matter can contribute to improving soil physical properties, biological activities, and nutrient availability. Due to the direct effects of these factors on plant growth, sugarcane management systems without burning may lead to higher yields over time compared to systems using preharvest burning (Wood, 1991; Resende et al., 2006).

In general, depending on the management of crop residues, changes in microbial biomass and soil activities may occur (Cattelan and Vidor, 1990), affecting nutrient cycling, plant growth, and soil quality in a broad sense (Altieri, 1999; Bastida et al., 2008). Therefore, understanding the connection between soil quality and plant production is important for understanding the impacts from the practice of not burning sugarcane in preharvest. This connection can be seen by evaluating soil microbial diversity and activity due to their role in soil functions and plant production (e.g., nutrient mineralization, $\mathrm{N}$ fixation, $\mathrm{P}$ solubilization and uptake, and soil aggregation) (Doran and Parkin, 1994; Barrios, 
2007). Thus, alterations in the soil microbial community can have an impact on sugarcane yield and may thus be useful for understanding the effects of sugarcane management on soil quality and functioning.

In vitro C-substrate utilization capacity (Biolog) is an indirect method useful for measuring the impact of agricultural management systems on soil microbial activity (Bending et al., 2002; Graham and Haynes, 2005). Metabolic activity measured by Biolog GN microplates was lower in sugarcane with preharvest burning than in a system without burning (Graham and Haynes, 2005). In a long-term study, lower rates of $\mathrm{C}$-substrate utilization were likewise observed in soils under forest managed through burning every two years compared to control plots without burning (Campbell et al., 2008).

Assessment of the structure of microbial communities in the soil can also be useful for detecting possible impacts of crop management systems on soil microbiota (Jansa et al., 2002; Oehl et al., 2003; Baumgartner et al., 2005; Bünemann et al., 2006; Chen et al., 2008; Smith et al., 2008; Wallis et al., 2010). Determination of significant shifts in the structure of the bacterial community, based on the profiles of $16 \mathrm{~S}$ rRNA gene amplicons after denaturing gradient gel electrophoresis (PCR-DGGE), were observed in soils under forest, pasture, organic, and conventional management systems (Cookson et al., 2007; Liu et al., 2007; Cenciani et al., 2009; Rachid et al., 2012).

Short-term and long-term studies are needed to evaluate the intensity and development of early impacts on the environment caused by changes in crop management. Soil biological properties that indicate important soil functions can be sensitive to environmental changes, and are useful tools for monitoring immediate variations in soil management (Lagomarsino et al., 2009; Epelde et al., 2014; Rao et al., 2014). Thus, it is important to monitor the early effects of sugarcane harvest without burning on soil microbial communities in order to predict possible changes in soil quality that might affect sugarcane yield. Considering the usefulness of soil biological properties and the importance of early monitoring of changes in management, we aimed to evaluate metabolic diversity and the structure of the bacterial community in the soil after the first sugarcane harvest without burning compared to management with preharvest burning. Considering the sensitivity of soil microbiology to environmental variations, we hypothesized that metabolic diversity and the structure of the bacterial community would be affected by eliminating burning as of the first sugarcane harvest.

\section{MATERIAL AND METHODS}

\section{Study area and soil sampling}

Soil samples were collected on December 12, 2005 from an experimental area in the municipality

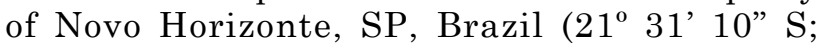
$\left.49^{\circ} 13^{\prime} 16^{\prime \prime} \mathrm{W}\right)$. The soil is a sandy clay loam Typic Eutrustox and the local climate is Aw according to the Köppen classification, with mean annual rainfall of $1,349 \mathrm{~mm}$ and mean annual temperature of $23.3{ }^{\circ} \mathrm{C}$. Prior to setting up the experiment on April 14, 2004, the area had grown the sugarcane variety SP711406, which was manually harvested 10 times with prior burning, and the area was subsequently planted to soybean. We evaluated soil samples under the sugarcane varieties SP813250, SP801842, and RB72454, harvested according to two management systems, i.e., with and without preharvest burning. Sugarcane varieties were planted with a $1.5 \mathrm{~m}$ spacing between rows using a completely randomized block design to better apply the harvest management systems. Each block was established in a strip containing three randomized plots of $15 \times 6 \mathrm{~m}$ for each variety in the field, i.e., in the strip with preharvest burning management, there were three random plots for each variety, and the same was done for the block without preharvest burning. Each block was harvested according to the harvest management system. The total number of samples was 18 (two harvest management systems $\times$ three sugarcane varieties $\times$ three replicates). Soil sampling was performed 84 days after the first harvest, collecting 10 random subsamples per plot from the $0-20 \mathrm{~cm}$ layer (0-10 and 10-20 cm for PCR-DGGE analysis) in the plant row. The samples were homogenized to end up with one sample per plot. Soil samples were air dried and sieved $(2 \mathrm{~mm})$ for chemical analyses. Samples for microbial biomass and metabolic diversity determinations were stored at $4{ }^{\circ} \mathrm{C}$, and samples for DNA extraction, at $-80{ }^{\circ} \mathrm{C}$ until processing.

\section{Soil chemical analyses}

Soil samples were used to determine $\mathrm{pH}, \mathrm{H}+\mathrm{Al}$, $\mathrm{Al}^{3+}, \mathrm{Ca}^{2+}, \mathrm{Mg}^{2+}, \mathrm{K}^{+}, \mathrm{Na}^{+}, \mathrm{P}$, organic carbon (OC), B, $\mathrm{Cu}, \mathrm{Fe}, \mathrm{Mn}, \mathrm{Zn}$, and cation exchange capacity at $\mathrm{pH}$ 7.0 (CEC), according to Silva (1999) and Raij et al. (2001) (Table 1).

\section{Microbial biomass $\mathrm{C}$ and metabolic profile}

A $10 \mathrm{~g}$ aliquot was used to determine microbial biomass C (MBC) by the fumigation-extraction method, according to Vance et al. (1987).

After determining the most probable number (MPN) of bacterial cells in the soil in a culture medium $(0.5 \%$ peptone, $0.3 \%$ meat extract, $1.0 \%$ $\mathrm{NaCl}$ ), an aliquot of suspended soil, containing $10^{3}$ to 
Table 1. Methods used to determine soil chemical properties under sugarcane without and with preharvest burning in three varieties (SP813250, SP801842, and RB72454)

\begin{tabular}{|c|c|c|}
\hline Property & Method or extractor & Reference \\
\hline $\mathrm{pH}$ & Measured in $0.01 \mathrm{~mol} \mathrm{~L}^{-1} \mathrm{CaCl}_{2}$ & Raij et al. (2001) \\
\hline $\mathrm{H}+\mathrm{Al}$ & pH in SMP buffer & Raij et al. (2001) \\
\hline Exchangeable Al & $1 \mathrm{~mol} \mathrm{~L}^{-1} \mathrm{KCl}$ & Raij et al. (2001) \\
\hline $\mathrm{P}$ and exchangeable $\mathrm{Ca}$ and $\mathrm{Mg}$ & Ion-exchanger resin & Raij et al. (2001) \\
\hline Exchangeable $\mathrm{K}$ and $\mathrm{Na}$ & Mehlich 1 & Silva (1999) \\
\hline Exchangeable $\mathrm{Cu}, \mathrm{Fe}, \mathrm{Mn}$, and $\mathrm{Zn}$ & DTPA & Raij et al. (2001) \\
\hline B & $\mathrm{BaCl}_{2}$ under microwave irradiation & Silva (1999) \\
\hline Organic carbon & $\mathrm{K}_{2} \mathrm{Cr}_{2} \mathrm{O}_{7}$ digestion & Raij et al. (2001) \\
\hline CEC (pH 7.0) & Sum of $\mathrm{H}+\mathrm{Al}, \mathrm{Ca}^{2+}, \mathrm{Mg}^{2+}, \mathrm{K}^{+}, \mathrm{Na}^{+}$ & Silva (1999) \\
\hline
\end{tabular}

$10^{4}$ cells $\mathrm{mL}^{-1}$, was inoculated into the wells of Biolog EcoPlates (Biolog Inc., Hayward, California, USA) using three replicates per plate, according to Insam (1997). After $48 \mathrm{~h}$ of incubation, the ability of the soil microorganisms to use a particular C-substrate was determined spectrophotometrically at $590 \mathrm{~nm}$ $\left(\mathrm{A}_{590}\right)$, according to Ibekwe and Kennedy (1998). Overall color development on the Biolog EcoPlates was expressed as the average well color development (AWCD), calculated as described by Garland and Mills (1991), i.e., $\mathrm{AWCD}=[\Sigma(C-R)] / n$, where $C$ is the absorbance in each well with C-substrates, $R$ is the absorbance value of the control (without a C-substrate), and $n$ is the number of wells with $\mathrm{C}$-substrates. The richness of $\mathrm{C}$-substrate utilization (Ss), the diversity of C-substrate utilization (Shannon, Hs), and the evenness of C-substrate utilization (Es) were determined according to Zak et al. (1994).

\section{Bacterial community structure}

For analysis of the bacterial community structure, we used samples from the 0-10 and 10-20 cm layers in the plant rows of the sugarcane variety SP801842 since we observed significant changes in soil microbial activity under this cultivar in response to the harvest management system. Total DNA was extracted from $500 \mathrm{mg}$ of soil using the Fast DNA kit (Qbiogene, Irvine, CA, USA), according to manufacturer's instructions. DNA integrity was determined by electrophoresis in 0.5X TBE-0.8\% agarose gels, after staining with Vista Green (GE Healthcare, São Paulo, Brazil). DNA concentration was determined by densitometry, using the Low DNA Mass Ladder (Invitrogen, São Paulo, Brazil) as a standard, and the Fragment Analyses program (GE Healthcare, São Paulo, Brazil).

The V3 region of the bacterial 16S rRNA gene was amplified by PCR using $50 \mathrm{ng}$ of the total soil DNA extracted as a template and the primers BA338fGC (5’ GCC CGC CGC GCG CGG CGG GCG GGG CGG GGG CAC GGA CTC CTA CGG GAG GCA GCA G 3') and UN518r (5' ATT ACC GCG GCT GCT GG 3')
(Øvreås et al., 1997). Amplification was performed in $1 \mathrm{X}$ recombinant Taq DNA polymerase buffer containing $0.2 \mathrm{mmol} \mathrm{L}^{-1} \mathrm{dNTPs}, 3 \mathrm{mmol} \mathrm{L}-1 \mathrm{MgCl}_{2}$, 1 U Taq DNA polymerase (Invitrogen, São Paulo, Brazil), 5 pmol of each primer, and $50 \mathrm{ng}$ of total DNA. PCR amplification conditions were $5 \mathrm{~min}$ at $95{ }^{\circ} \mathrm{C}$; 30 cycles of $1 \mathrm{~min}$ at $95{ }^{\circ} \mathrm{C}, 1 \mathrm{~min}$ at $55^{\circ} \mathrm{C}$, and $1 \mathrm{~min}$ at $72^{\circ} \mathrm{C}$; and final extension for $10 \mathrm{~min}$ at $72^{\circ} \mathrm{C}$. The concentration of PCR products (amplicons) was determined by densitometry, after electrophoresis in 0.5X TBE-0.8 \% agarose gels and staining with Vista Green (GE Healthcare, São Paulo, Brazil), using the Low DNA Mass Ladder (Invitrogen, São Paulo, Brazil) as a standard, a FluorImager laser densitometer (GE Healthcare, São Paulo, Brazil), and the Fragment Analyses program (GE Healthcare, São Paulo, Brazil).

Amplicons (300 ng) were analyzed by DGGE using $8 \%(\mathrm{w} / \mathrm{v})$ acrylamide:bisacrylamide (37.5:1, $\mathrm{m}: \mathrm{m})$ gels containing a 15 to $55 \%$ linear gradient of formamide and urea (100\% denaturing solution contained $40 \%$ formamide and $7 \mathrm{~mol} \mathrm{~L}^{-1}$ urea) according to Øvreås et al. (1997). Electrophoresis was performed at $200 \mathrm{~V}$ constant and $60^{\circ} \mathrm{C}$, using a DCode System (BioRad, Hercules, CA, USA) in a 1X TAE buffer. Gels were stained with Vista Green (GE Healthcare, São Paulo, Brazil) and analyzed by densitometry, using a FluorImager laser densitometer (GE Healthcare, São Paulo, Brazil) and the program Diversity Database (BioRad, Hercules, CA, USA).

\section{Statistical analysis}

The Barlett test was used to evaluate homogeneity of variance, and the Shapiro Wilk test for evaluation of normality. For normalization, AWCD and Hs data were transformed to $\mathrm{x}^{0.5}$, according to the indications of SAS. The GLIMMIX procedure of SAS 9.2 (Littell et al., 2006) was used to test the effects of harvest management (MANAGEMENT factor) and varieties (VARIETY factor) under the completely randomized block design. Means were compared using the Tukey-Kramer test $(\mathrm{p}<0.05)$. 
To evaluate the effects of sugarcane preharvest burning on microbial communities, chemical data, and consumption of $\mathrm{C}$-substrates, as determined using Biolog EcoPlates, discriminant analysis was performed using the Systat 11 software (SPSS Inc.).

To determine the influence of environmental variables on variance in utilization of $\mathrm{C}$-substrates by soil microbiota under sugarcane, redundancy analysis (RDA) was performed using the "Canoco for Windows 4.5" and transforming the data to $\log \mathrm{x}$. To eliminate data co-linearity and select the variables that significantly explain data variability, the forward selection method and the Monte Carlo test was used in RDA. Group centroid coordinates for each harvest management system were calculated as the mean of the coordinates of group members.

DGGE banding patterns (amplicon profiles), representing the bacterial community structure in the soil, were analyzed as discrete data (presence or absence of bands with the same mobility in the gel, $R_{f}$ ) using Hierarchical Clustering Analysis based on simple matching similarity matrices calculated using the Ward algorithm and Euclidian distances
(Systat, SPSS Inc.), and Principal Component Analysis (PCA) for ordering the data.

\section{RESULTS}

\section{Soil chemical properties}

Soil OC content did not differ significantly between the two harvest management systems (Table 2). However, the concentrations of $\mathrm{Al}^{3+}$ and $\mathrm{Cu}^{2+}$ were higher in the soil samples from the plots without preharvest burning of sugarcane $(p<0.05)$ (Table 2). Soil B concentration was statistically higher in samples from plots with preharvest burning. The soil OC contents were higher in samples from plots under sugarcane variety RB72454 without preharvest burning compared to the samples under the other varieties. Soil $\mathrm{pH}$ was higher in the samples from plots under variety SP813250 than in plots under variety SP801842 with preharvest burning (Table 3).

Table 2. F values of two factor ANOVA (harvest management practice and sugarcane variety), according to soil chemical variable, metabolic profile, and yield of sugarcane

\begin{tabular}{|c|c|c|c|}
\hline Variable & Management practice (M) & Variety (V) & Interaction $(\mathrm{M} \times \mathrm{V})$ \\
\hline \multicolumn{4}{|l|}{ Soil } \\
\hline $\mathrm{pH}\left(\mathrm{CaCl}_{2}\right)$ & 2.81 & 0.09 & 2.14 \\
\hline $\mathrm{H}+\mathrm{Al}$ & 0.11 & 0.06 & 0.35 \\
\hline $\mathrm{Al}^{3+}$ & $5.59 *$ & 0.31 & 0.15 \\
\hline $\mathrm{Ca}^{2+}$ & 0.06 & 0.07 & 0.56 \\
\hline $\mathrm{Mg}^{2+}$ & 3.77 & 1.00 & 1.46 \\
\hline $\mathrm{K}^{+}$ & 0.62 & 1.41 & 1.99 \\
\hline $\mathrm{Na}^{+}$ & 4.17 & $5.34^{*}$ & 0.06 \\
\hline $\mathrm{P}$ & 2.88 & 1.68 & 1.16 \\
\hline B & $9.51^{* *}$ & 1.47 & 2.41 \\
\hline $\mathrm{Cu}$ & $20.83^{* * *}$ & 0.68 & 0.16 \\
\hline $\mathrm{Fe}$ & 3.56 & 0.09 & 1.49 \\
\hline $\mathrm{Mn}$ & 0.09 & 2.32 & 1.65 \\
\hline $\mathrm{Zn}$ & $4.86^{*}$ & 0.50 & 1.77 \\
\hline Organic carbon & 0.00 & 3.39 & $5.76^{*}$ \\
\hline CEC & 0.39 & 0.35 & 0.62 \\
\hline Base saturation $(\mathrm{V})$ & 0.22 & 0.12 & 0.51 \\
\hline MBC & 0.35 & 1.40 & 0.38 \\
\hline \multicolumn{4}{|l|}{ Metabolic profile } \\
\hline AWCD & $14.02^{* *}$ & $6.83^{*}$ & $6.53^{*}$ \\
\hline Ss & $27.99 * * *$ & $7.73^{* *}$ & $14.05^{* * *}$ \\
\hline $\mathrm{Hs}$ & $10.10^{* *}$ & 3.32 & $4.56^{*}$ \\
\hline Es & $17.49^{* *}$ & $6.70^{*}$ & $10.98^{* *}$ \\
\hline \multicolumn{4}{|l|}{ Sugarcane yield } \\
\hline TSH & 4.61 & 0.11 & 1.50 \\
\hline
\end{tabular}

Significant differences: $*$, ** and $* * *: p<0.05,0.01$ and 0.001, respectively; MBC: microbial biomass carbon; AWCD: average well color development; TSH: $\mathrm{t} \mathrm{ha}^{-1}$ of stalks; Ss: richness of C-substrate utilization; Hs: the Shannon index; Es: the evenness of substrate utilization index. Values are mean \pm standard deviation. 


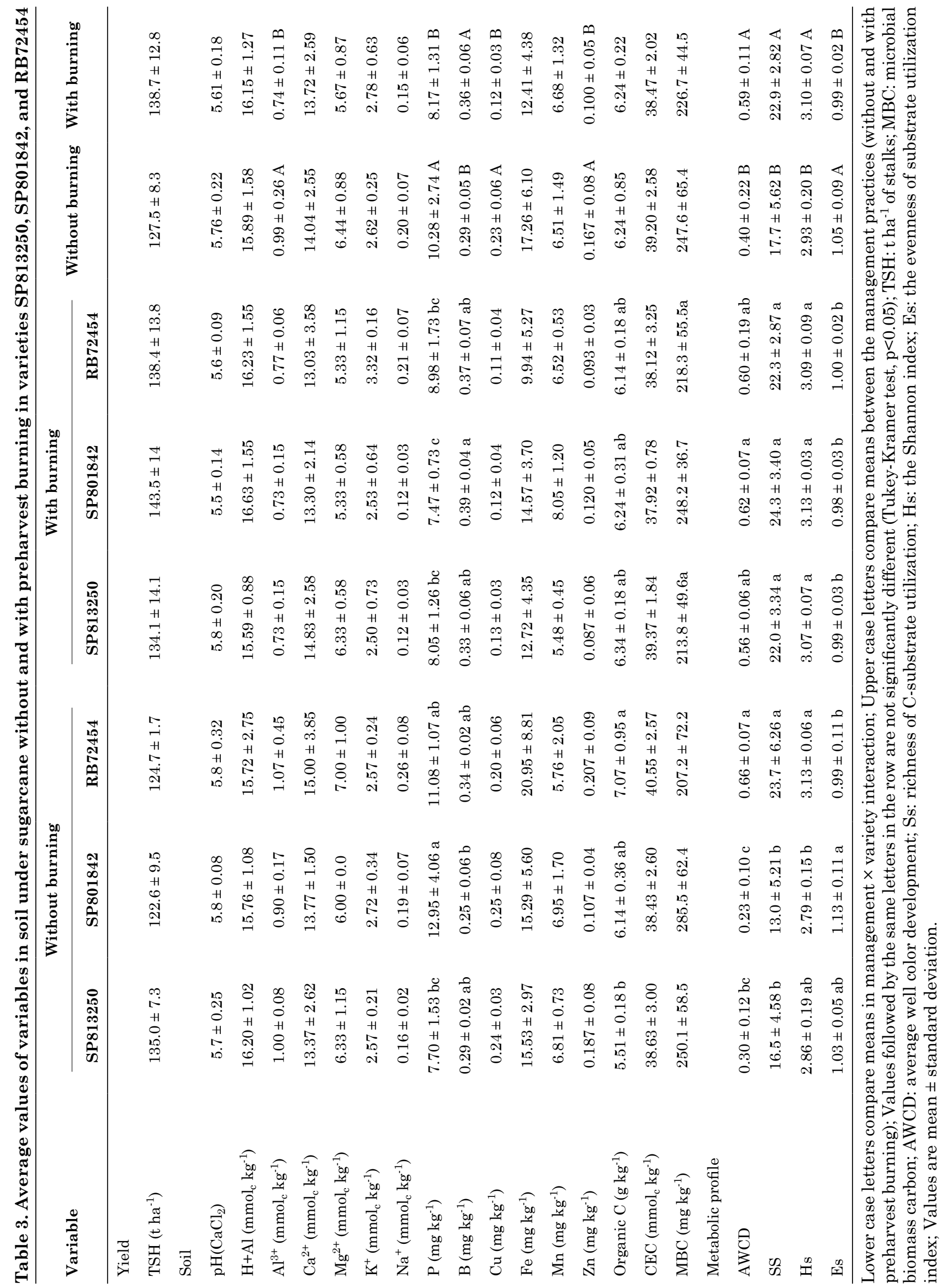




\section{Microbial biomass and metabolic profile}

Soil MBC concentration ranged from 217 to $286 \mathrm{mg} \mathrm{kg}^{-1}$ (Table 3) and did not show statistically significant differences when comparing harvest management (with and without preharvest burning), sugarcane varieties $(\mathrm{p}>0.05)$, or the interaction between harvest management and variety (Table 3 ).

Microbial activity (evaluated by AWCD), richness of C-substrate utilization (Ss), and metabolic diversity, expressed by the Shannon index (Hs), as well as the evenness of substrate utilization index (Es), showed statistical differences when comparing the two management systems, and the interactions of the management and variety factors $(p<0.05$, Table 3). In general, the treatments without burning showed 32.2, 22.7, and 5.4\% lower AWCD, Ss, and $\mathrm{Hs}$ values respectively, than in treatments with preharvest burning (Table 3). In contrast, Es was $6.1 \%$ higher in the treatments without preharvest burning than in the treatments with burning.

Without preharvest burning, AWCD, Ss, and $\mathrm{Hs}$ were higher in the soil planted to variety RB72454 than in soil growing other varieties. Changes in $\mathrm{AWCD}, \mathrm{Ss}, \mathrm{Hs}$, and $\mathrm{Es}$ between the harvest management systems were most pronounced within variety SP801842 $(63 \%, \mathrm{p}=0.0018 ; 47 \%, \mathrm{p}=0.0017$; $11 \%, \mathrm{p}=0.0071$; and $15 \%, \mathrm{p}<0.0001$, respectively) (Table 3).

Discriminant analysis using soil chemical properties or C-substrate utilization as discriminating factors showed no significant differences between soil samples without and with preharvest burning (Wilks' lambda test, $\mathrm{p}>0.05$ ). Redundancy analysis (RDA) was also carried out to better explain C-substrate utilization by microbiota. Soil organic C, P, and B concentrations were chosen by forward selection and are the variables that best explain the variability of $\mathrm{C}$-substrate utilization data, according to Monte Carlo permutation tests. The two first axes of RDA explained $22.0 \%$ (16.4\% was explained by axis 1 and $5.6 \%$ by axis 2 ) of the data variability, and suggest that there are significant differences between samples from soils under sugarcane harvested without and with the use of burning (Figure 1). A Monte-Carlo test showed that axis $1(p=0.013)$ and the sum of the canonical axes $(p=0.047)$ were significant, indicating that the levels of organic C, P, and B in the soil significantly influence $\mathrm{C}$-substrate utilization by the microbiota. The patterns of C-substrate utilization in soil planted to sugarcane without preharvest burning were associated with higher soil $\mathrm{P}$ levels, whereas the patterns of $\mathrm{C}$-substrate utilization in soil with preharvest burning were associated with higher soil B levels, as shown using univariate analysis (Table 3). Axis 1 did not segregate samples from the two harvest management systems. However, most samples from systems without preharvest burning were on the positive side, whereas most samples from the system using preharvest burning were on the negative side. Axis 2, in turn, tended to discriminate the two management systems. Six out of the nine samples from the system with no preharvest burning were on the positive side of axis 2 , and seven out of the nine samples from the system with preharvest burning were on the negative side. In addition, the centroids of the samples from the two preharvest treatments were in opposite quadrants (Figure 1).

According to the distribution of the samples in figure 1, we observed that the soil samples from the system without burning were associated with greater consumption of L-threonine (amino acid); D-mannitol (carbohydrate); D-galacturonic acid, 4-hydroxybenzoic acid, and Y-hydroxybutyric acid (carboxylic acids); Tween 40 and Tween80 (polymers); and D,L-a-glycerol phosphate (miscellaneous). In contrast, the soil samples from the system with preharvest burning were associated with

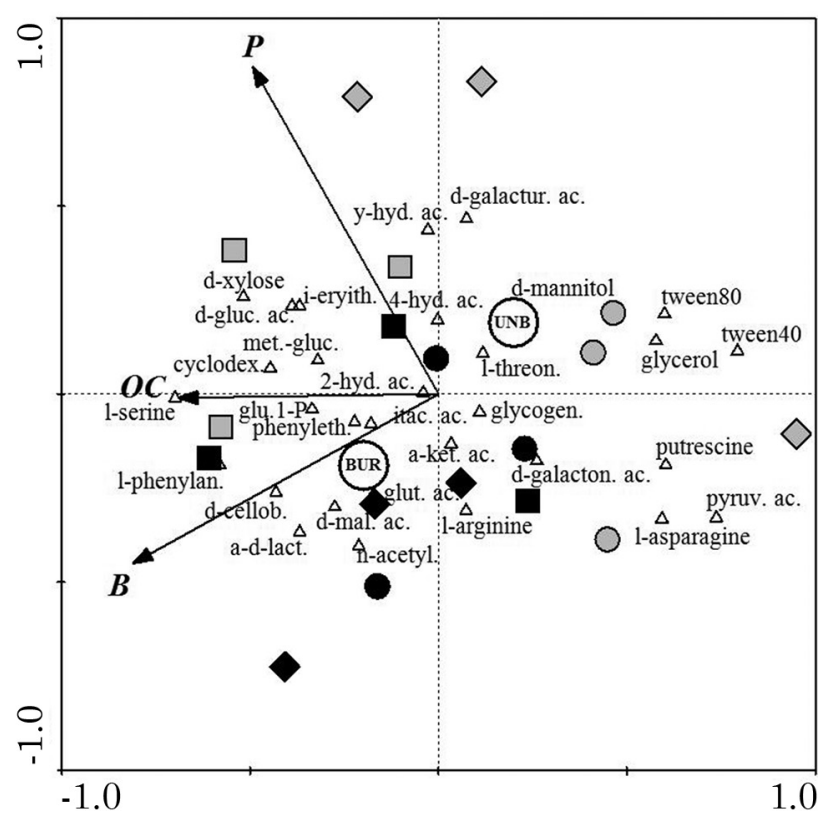

Figure 1. Redundancy Analysis Triplot (RDA) using carbon substrates, soil variables (OC: organic carbon, P: phosphorus, and B: boron), and samples $(O, \diamond, \square$ - without preharvest burning and,$\square$ - with preharvest burning, in the varieties SP813250, SP801842, and RB72454, respectively). The first two canonical axes are shown. The first axis explained $16.4 \%$ and the second explained $5.6 \%$ of the data variability. Environmental properties were selected through forward selection. According to the Monte Carlo permutation test, $p=0.013$ for the first canonical axis, and $p=0.047$ for all canonical axes. UNB - centroid for samples from unburned management; BUR - centroid for samples with burned management. 
higher consumption of phenylethylamine (amine); L-arginine, L-phenylalanine, and L-serine (amino acids); N-acetyl-D-glucosamine, a-D-lactose, and D-cellobiose (carbohydrates); D-malic acid, itaconic acid, and a-ketobutyric acid (carboxylic acids); and L-glucose-phosphate (miscellaneous).

\section{Bacterial community structure}

To investigate whether changes in soil metabolic profile were associated with changes in bacterial community structure, we used PCR-DGGE of the $\mathrm{V} 3$ region of the $16 \mathrm{~S}$ rRNA gene from soil samples planted to the sugarcane variety SP801842. We chose soil samples under this genotype due to the effect of the harvest management system on microbial metabolic capacity and the diversity observed (Table 3). Furthermore, we evaluated the bacterial community structure at the 0-10 and $10-20 \mathrm{~cm}$ depths to better understand the effects of crop residues on the soil microbiota. The DGGE analyses revealed 120 amplicons with different mobility $\left(R_{f}\right)$ in the gel (Figure 2 ). The presence or absence of amplicons with a specific $R_{f}$ was used to compare the bacterial community structures of different samples. Hierarchical clustering analysis showed distinct bacterial communities in soil samples from different depths and harvest management systems (Figure 3). However, the bacterial community structures in soil samples from the systems without preharvest burning at the $0-10 \mathrm{~cm}$ depth were more similar to each other than to the other samples. Sample ordination was assessed using the presence or absence of amplicons through DGGE data and Principal Component Analysis (PCA). However, there was no sample clustering associated with the harvest management system (data not shown).

\section{DISCUSSION}

There was no statistical difference in soil OC content 84 days after first harvest in soil samples without and with preharvest burning (Table 3). Crop residues were still visible on the soil surface at the time of sampling due to the short time interval after the first harvest. The MBC content also did not differ among treatments, suggesting that the amount of $\mathrm{C}$ from the crop residues was not enough to induce detectable changes in MBC, and that burning does not induce early changes in $\mathrm{MBC}$, i.e., compared to MBC after the first harvest without burning. Some studies show similar results, with no changes in MBC after a single burning in forests (Wüthrich et al., 2002; Hamman et al., 2007; Kara and Bolat, 2009). However, differences in MBC are observed when burning occurs several times, including in sugarcane (Ojima et al., 1994; Ajwa et al., 1999; Souza et al., 2012). In contrast, Jensen et al. (2001)

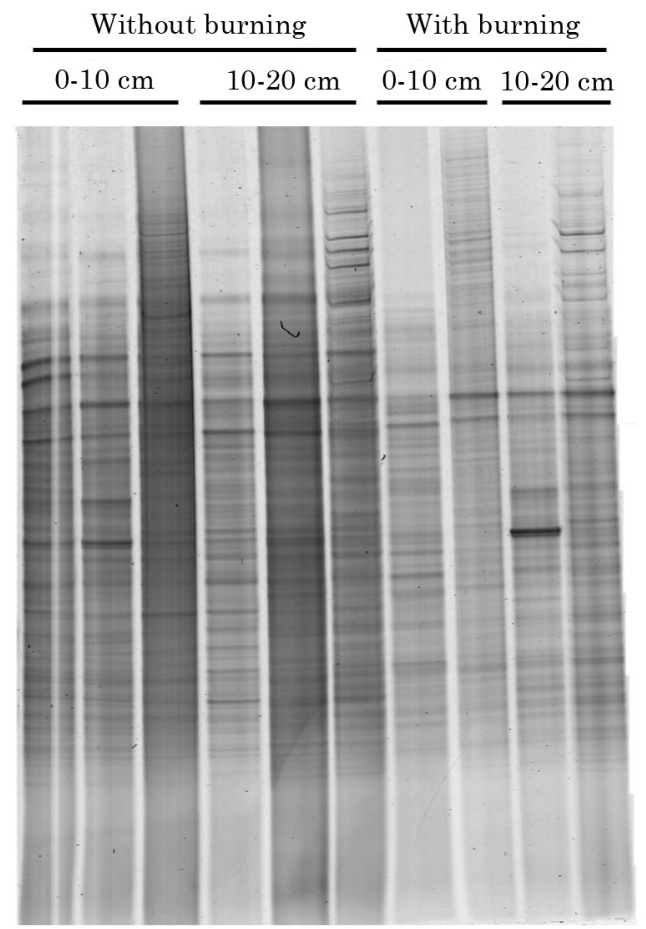

Figure 2. PCR-DGGE of the 16S rRNA gene from the bacterial communities in the $0-10$ and $10-20 \mathrm{~cm}$ layers of soils under the sugarcane variety SP801842 harvested without or with preharvest burning.

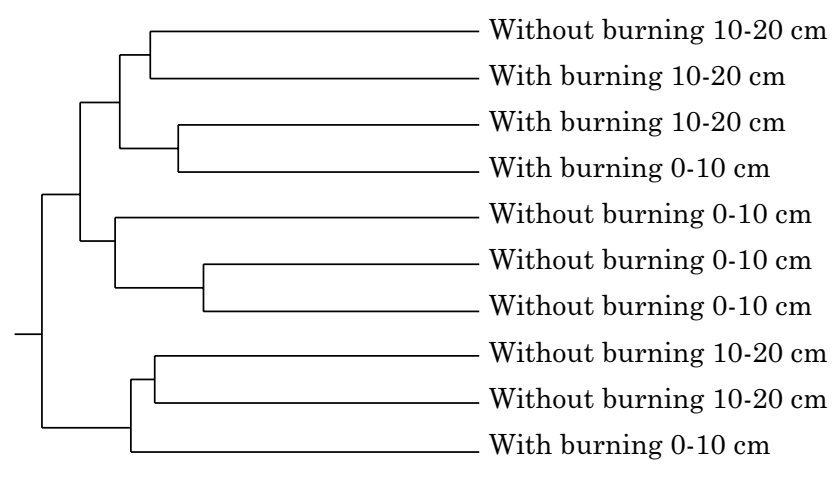

$\begin{array}{llllllll}0.8 & 0.7 & 0.6 & 0.5 & 0.4 & 0.3 & 0.2 & 0.1\end{array}$

Euclidean distance

Figure 3. Hierarchical clustering analyses of bacterial communities based on the profiles of 16S rRNA gene amplicons after DGGE in the 0-10 and 10-20 cm layers of soils under the sugarcane variety SP801842 harvested without or with preharvest burning.

showed a transient increase in MBC after a low severity fire on a woodland savanna in Ethiopia. A slight increase in MBC was also detected on sites of prairie grassland burned for one or two years in Kansas, USA (Ojima et al., 1994). It is likely that the 
effects of fire on MBC depend on the severity of the fire (temperature and duration), and the amounts of nutrients released from organic matter after the fire. In our study, the MBC after the first harvest of sugarcane in soil samples without burning was not different from the samples with burning, probably because of the low increases in soil temperature observed during sugarcane preharvest burning (Barbieri and Silva, 2008). At a depth of $5 \mathrm{~mm}$, the soil temperature increases $7.6{ }^{\circ} \mathrm{C}$ (from 25.0 to $32.6{ }^{\circ} \mathrm{C}$ ) when burning at $2: 00 \mathrm{pm}$, and $5.8^{\circ} \mathrm{C}$ (from 26.7 to $32.5^{\circ} \mathrm{C}$ ) at $6: 00 \mathrm{pm}$. The temperature reaches these values in the occurrence of fire in approximately $50 \mathrm{~min}$ (Barbieri and Silva, 2008).

Evenness of C-substrate utilization (Es), a measure of the equitability of activities across all substrates utilized, was higher in soil samples from systems without burning. Harvest without burning reduced AWCD (overall $\mathrm{C}$ utilization), and the richness $(\mathrm{Ss})$ and diversity $(\mathrm{Hs})$ of $\mathrm{C}$-substrate utilization compared to the preharvest burning treatment (Table 3). In contrast, studies on sugarcane performed in Australia showed that soil metabolic activity and diversity decrease with preharvest burning (Graham and Haynes, 2005). However, the authors evaluated soil microbial activity over several years of sugarcane cropping, with and without preharvest burning. It is possible that the lower metabolic activity and microbial diversity in soil samples from systems without burning observed in our experiment is transient, and may increase with successive croppings. Using Biolog EcoPlates, Fontúrbel et al. (2012) likewise observed higher AWCD, Ss, and Hs at 90 days after burning, but not at 180 and 365 days after burning, compared to sites without burning, in a shrubland area in Galicia (Spain). Higher MBC (52\%) and basal respiration (20\%) were observed in plots with burning than in plots without burning in a savanna in Africa (Andersson et al., 2004). These differences were observed 12 days after burning and decreased over time.

The increase in microbial activity observed after short-term or low severity fire may be associated with the release of mineral nutrients during the combustion of organic matter (Ojima et al., 1994; Yinghua et al., 2012). However, repeated burning would result in poor quality material inputs in the soil, with consequent reduction in plant residues added to the soil and decreases in microbial biomass and activity (Ojima et al., 1994). As for soil nutrients, in our study, we observed lower B content in treatments without burning comparing to treatments with burning, based on comparisons of mean values and RDA. A lower B content could contribute to reduced microbial activity in treatments without burning compared to treatments with burning. There is little evidence of B stimulating bacterial activity. However, B has been reported as an important nutrient for cyanobacteria (Mateo et al., 1986), for some actinomycetes (e. g., Frankia) (Bolanos et al., 2002), and for boron tolerant bacterium (Ahmed et al., 2007). As a result, our data showed that, at least after the first harvest of sugarcane, microbial metabolism in systems with preharvest burning may be more highly stimulated than in the system without burning.

In soil samples from the system without burning, we observed an effect of sugarcane variety on soil microbial metabolism (AWCD, Ss, Hs, and s (Table 3). Even though there is no information on the chemical composition of the rhizosphere of the sugarcane genotypes evaluated, it is possible that the differences in microbial metabolism observed in our experiment are due to the chemical composition of root exudates, or differences in root architecture and/or development that stimulate specific populations within soil microbial communities. Differences in morphological and physiological features of roots among sugarcane cultivars may exist, as reported for the uptake capacity per unit of dry matter and for root branching, suggesting differences in the efficiency of $\mathrm{C}$ allocation and in acquisition of water and nutrients among sugarcane genotypes (Smith et al., 2005). Additionally, other studies have shown differences in the soil microbiota due to the plant genotype and its rhizospheric effect (Marschner et al., 2006; Schweitzer et al., 2008; Micallef et al., 2009). Changes in the structure of the microbial community and functional diversity due to plant genotype were also observed by Dunfield and Germida (2001) analyzing fatty acid profiles and C-substrate utilization in the rhizosphere of Brassica spp. Maloney et al. (1997) suggest that differences in the relationship between oligotrophic and copiotrophic bacteria in the rhizosphere of tomato and lettuce are also associated with exudate composition or root morphology. Since we analyzed a mixture of non-rhizospheric and rhizospheric soil, it is likely that the effects of sugarcane root morphology and exudate composition could be higher if rhizospheric soil alone were sampled.

In addition to evaluating the statistical differences between AWCD treatments, analyzing individual C-substrates as a group can help clarify the effects of harvest management practices and varieties. Thus, multivariate analysis was performed to show correlations among the variables. Discriminant analysis based on either C-substrate utilization by edaphic microbiota or soil chemical properties did not result in sample clustering by management type (data not shown).

However, RDA of specific chemical properties and the profile of $\mathrm{C}$-substrate utilization suggested a clear discrimination of samples by management type (Figure 1). Organic C, P, and B contents affect soil biological activity. Organic $\mathrm{C}$ content is one of the main factors that influence soil metabolism 
(Schnürer et al., 1985; Wardle, 1992). P is frequently a limiting nutrient in tropical soils (Khasawneh et al., 1980) and can influence bacterial metabolism in the soil (Alden et al., 2001; Oberson et al., 2001). B is also considered an important nutrient for some bacterial groups (Mateo et al., 1986; Bolanos et al., 2002, Ahmed et al., 2007). Considering the use of RDA, combined analysis of biological and soil chemical data can be used to detect early changes in the microbial community structure associated with the sugarcane harvest management system. RDA also showed that stimuli for the soil microbial communities to consume certain C-substrates depend on the preharvest management system.

Based on our Biolog EcoPlates data, the microbial community of the soil from the system without burning has less ability to use amines, amino acids, and carbohydrates, and higher consumption of polymers compared to the microbial community of the soil from the system with preharvest burning, suggesting that avoiding burning may enhance the ability of the microbial community in degrading complex substrates.

However, changes in C-substrate consumption, AWCD, Ss, Hs, and Es in the soil under sugarcane variety SP801842 were not associated with changes in the bacterial community structure determined by PCR-DGGE. Analyses using hierarchical clustering and PCA of $16 \mathrm{~S}$ rRNA amplicon profiles after DGGE did not show similarities between the bacterial community structures under the same harvest management system. However, changes in functional diversity are not always accompanied by changes in the genetic structure of the microbial community (Smalla et al., 1998). This lack of association may be due to the presence of organisms in dormant or latent states that may become active when the environment changes, for instance. A reversible transition between active and dormant states in soil microorganisms was observed by Stenström et al. (2001), who evaluated soil microbial respiration kinetics after adding different amounts of glucose to the soil. The authors suggested that shifting between active and dormant physiological states occurs rapidly and depends on substantial substrate amendment. Even though similar mechanisms may explain our results, further investigation would be necessary to explain the changes in microbial metabolism observed in our study.

Additionally, PCR-DGGE may be less sensitive in detecting shifts in the bacterial community than the metabolic profile is. Mijangos et al. (2009) observed that Biolog was more sensitive in detecting changes in microbial communities than PCR-DGGE when comparing soil under triticale and pea treated with glyphosate. It is likely that the universal primers used for amplification of 16S rRNA genes (e.g. for bacteria) would only detect large differences among the communities, whereas primers specific to different groups of microorganisms would be more sensitive (Ritz et al., 2004). In contrast, Rachid et al. (2012), using PCR-DGGE of the 16S rRNA gene, detected shifts in the soil bacterial community structure in a system without burning after 6 years of growing and cutting cycles.

In our study, metabolic profiling based on C-substrate utilization was more sensitive than MBC and PCR-DGGE in detecting early changes in the microbial community due to the sugarcane harvest management system. This conclusion indicates that the use of culture-dependent techniques to study soil microbial communities is still adequate for several situations and cannot be replaced by culture-independent techniques (Edenborn et al., 2011). Therefore, we suggest that Biolog Ecoplates are a more suitable way than MBC and PCR-DGGE of the $16 \mathrm{~S}$ rRNA gene for monitoring initial changes in soil microbiological properties resulting from changes in agricultural management practices.

\section{CONCLUSIONS}

After the first sugarcane harvest with no burning, microbial metabolic capacity and diversity were lower than in the system with burning.

There were no changes in the soil bacterial community structure detected by PCR-DGGE under sugarcane variety SP 801842 between the management systems with and without preharvest burning.

The metabolic profile is a more sensitive indicator than MBC and PCR-DGGE of the 16S rRNA gene for early changes in the soil microbial community caused by the harvest management system, and this profile can be a useful tool for monitoring sugarcane crop practices.

\section{ACKNOWLEDGMENTS}

The authors would like to thank the MSc. Rene de Assis Sordi (Assessor de Tecnologia Agronômica, Grupo São Martinho, Centro de Tecnologia Canavieira - CTC) and Dr. Carlos Suguitani (CTC) for providing the experimental area and the sugarcane yield analysis. L.C.B. Azevedo would like to thank the National Council for Scientific and Technological Development (CNPq), the Brazilian Office for Refinement of Personnel in Higher Education (CAPES), and the São Paulo Research Foundation (FAPESP) for scholarships at various times during his $\mathrm{PhD}$. M. Morais would like to thank CAPES for his PhD scholarship. We also thank three anonymous reviewers for their constructive comments. 


\section{REFERENCES}

Ahmed I, Yokota A, Fujiwara T. A novel highly boron tolerant bacterium, Bacillus sp. nov., isolated from soil, that requires boron for its growth. Extremophiles. 2007;11:217-24.

Ajwa HA, Dell CJ, Rice CW. Changes in enzyme activities and microbial biomass of tallgrass prairie soil as related to burning and nitrogen fertilization. Soil Biol Biochem. 1999;31:769-77.

Alden L, Demoling F, Bååth E. Rapid method of determining factors limiting bacterial growth in soil. Appl Environ Microbiol. 2001;67:1830-8.

Altieri MA. The ecological role of biodiversity in agroecosystems. Agric Ecosyst Environ. 1999;74:19-31.

Andersson M, Michelsenb A, Jensenb M, Kjøller A. Tropical savannah woodland: Effects of experimental fire on soil microorganisms and soil emissions of carbon dioxide. Soil Biol Biochem. 2004;36:849-58.

Barbieri V, Silva FC. Influência da queimada nas temperaturas dos colmos da cana-de-açúcar e da superfície do solo. Holos Environ. 2008;8:45-52.

Barrios E. Soil biota, ecosystem services and land productivity. Ecol Econ. 2007;64:269-85.

Bastida F, Zsolnay A, Hernández T, García C. Past, present and future of soil quality indices: A biological perspective. Geoderma. 2008;147:159-71.

Baumgartner K, Smith RF, Bettiga L. Weed control and cover crop management affect mycorrhizal colonization of grapevine roots and arbuscular mycorrhizal fungal spore populations in a California vineyard. Mycorrhiza. 2005;15:111-9.

Bending GD, Turner MK, Jones JE. Interactions between crop residue and soil organic matter and the functional diversity of soil microbial communities. Soil Biol Biochem. 2002;34:1073-82.

Bolanos L, Redondo-Nieto M, Bonilla I, Wall LG. Boron requirement in the Discaria trinervis (Rhamnaceae) and Frankia symbiotic relationship. Its essentiality for Frankia BCU110501 growth and nitrogen fixation. Physiol Plant. 2002;115:563-70.

Bünemann EK, Schwenke GD, van Zwieten L. Impact of agricultural inputs on soil organisms - a review. Aust J Soil Res. 2006;44:379-406

Campbell CD, Cameron CM, Bastias BA, Chen C, Cairney JWG. Long term repeated burning in a wet sclerophyll forest reduces fungal and bacterial biomass and responses to carbon substrates. Soil Biol Biochem. 2008;40:2246-52.

Cançado JED, Saldiva PHN, Pereira LAA, Lara LBLS, Artaxo P, Martinelli LA, Arbex MA, Zanobetti A, Braga ALF. The impact of sugar cane-burning emissions on the respiratory system of children and the elderly. Environ Health Perspect. 2006;114:725-9.

Cattelan AJ, Vidor C. Flutuações na biomassa, atividade e população microbiana do solo, em função de variações ambientais. R Bras Ci Solo. 1990;14:133-42.

Cenciani K, Lambais MR, Cerri CC, Azevedo LCB, Feigl BJ. Bacteria diversity and microbial biomass in forest, pasture and fallow soils in the southwestern amazon basin. R Bras Ci Solo. 2009;33:907-16.

Chen Y, Mcnamara NP, Dumont MG, Bodrossy L, Stralis-Pavese $\mathrm{N}$, Murrel JC. The impact of burning and Calluna removal on below-ground methanotroph diversity and activity in a peatland soil. Appl Soil Ecol. 2008;40:291-8.

Companhia Nacional do Abastecimento - Conab. Acompanhamento da Safra Brasileira - Cana-de-Açúcar. Ministério da Agricultura. Accessed: Jun. 24, 2014. Available at: http://www.conab.gov.br.

Cookson WR, Osman M, Marschner P, Abaye DA, Clark I, Murphy DV, Stockdale EA, Watson, CA. Controls on soil nitrogen cycling and microbial community composition across land use and incubation temperature. Soil Biol Biochem. 2007;39:744-56.

Doran JW, Parkin TB. Defining and assessing soil quality. Madison: Soil Science Society of America; 1994. (Special publication, 35).

Dunfield KE, Germida JJ. Diversity of bacterial communities in the rhizosphere and root interior of field-grown genetically modified Brassica napus. FEMS Microbiol Ecol. 2001;38:1-9.

Edenborn SL, Sextone AJ, Sutanto Y, Chapman JA. Relationships among contrasting measurements of microbial dynamics in pasture and organic farm soils. Appl Environ SoilSci. 2012 Accessed: Nov. 01, 2012. Available at: http://www.hindawi.com/ journals/aess/2011/537459/.

Epelde L, Burges A, Mijangos I, Garbisu C. Microbial properties and attributes of ecological relevance for soil quality monitoring during a chemical stabilization field study. Appl Soil Ecol. 2014;75:1-12.

Fontúrbel MT, Barreiro A, Vega JA, Martín A, Jiménez E, Carballas T, Fernández C, Díaz-Raviña M. Effects of an experimental fire and post-fire stabilization treatments on soil microbial communities. Geoderma. 2012;191:51-60.

Galdos MV, Cerri CC, Cerri CEP. Soil carbon stocks under burned and unburned sugarcane in Brazil. Geoderma. 2009;153:347-52.

Galdos MV, Cerri CC, Lal R, Bernoux M, Feigl BJ, Cerri CEP. Net greenhouse gases fluxes in Brazilian ethanol production systems. GCB Bioenergy. 2010;2:37-44.

Garland JL, Mills A. Classification and characterization of heterotrophic microbial communities on the basis of patterns of community-levels-sole-carbon-source-utilization. Appl Environ Microbiol. 1991;57:2351-9.

Graham MH, Haynes RJ. Catabolic diversity of soil microbial communities under sugarcane and other land uses estimated by Biolog and substrate-induced respiration methods. Appl Soil Ecol. 2005;29:155-64.

Hamman ST, Burke IC, Stromberger ME. Relationships between microbial community structure and soil environmental conditions in a recently burned system. Soil Biol Biochem. 2007;39:1703-11.

Ibekwe AM, Kennedy AC. Phospholipid fatty acid profiles and carbon utilization patterns for analysis of microbial community structure under yield and greenhouse conditions. FEMS Microbiol Ecol. 1998;26:151-63.

Insam H. A new set of substrates proposed for community characterization in environmental samples. In: Insam H, Rangger A, editors. Microbial communities. Functional versus structural approaches. New York: Springer; 1997. p.259-60.

Intergovernmental Panel on Climate Change - IPCC. Climate change in 1994: Radiative forcing of climate change. Cambridge: Cambridge University Press; 1995. 
Jansa J, Mozafar A, Anken T, Ruh R, Sandeers IR, Frossard E. Diversity and structure of AMF communities as affected by tillage in a temperate soil. Mycorrhiza. 2002;12:225-34.

Jensen M, Michelsen A, Gashaw M. Responses in plant, soil inorganic and microbial nutrient pools to experimental fire, ash and biomass addition in a woodland savanna. Oecologia. 2001;128:85-93.

Kara O, Bolat I. Short-term effects of wildfire on microbial biomass and abundance in black pine plantation soils in Turkey. Ecol Indic. 2009;9:1151-5.

Khasawneh FE, Sample EC, Kamprath EJ. Management considerations for acid soils with high phosphorus fixation capacity. In: Khasawneh FE, Sample EC, Kamprath EJ, editors. The role of phosphorus in agriculture. Madison: American Society of Agronomy, Crop Science Society of America/Soil Science Society of America; 1980. p.471-514.

Lagomarsino A, Moscatelli MC, Di Tizio A, Mancinelli R, Grego $\mathrm{S}$, Marinari S. Soil biochemical indicators as a tool to assess the short-term impact of agricultural management on changes in organic $\mathrm{C}$ in a Mediterranean environment. Ecol Indic. 2009;9:518-27.

Littell RC, Milliken GA, Stroup WW, Wolfinger RD, Schabenberger O. SAS for mixed models. $2^{\text {nd }}$.ed. Cary: SAS Institute; 2006.

Liu B, Tu C, Hu S, Gumpertz M, Ristaino JB. Effect of organic, sustainable, and conventional management strategies in grower fields on soil physical, chemical, and biological factors and the incidence of Southern blight. Appl Soil Ecol. 2007;37:202-14.

Machado W, Teles TS, Tavares-Filho J, Guimarães MF, Alves GB, Borges JLB. Physical properties of a Rhodic Haplustox under two sugarcane harvesting systems. R Bras Ci Solo. 2010;34:1803-9.

Maloney PE, van Bruggen, AHC, Hu S. Bacterial community structure in relation to the carbon environments in lettuce and tomato rhizospheres and in bulk soil. Microb Ecol. 1997;34:109-17.

Marschner P, Solaiman Z, Rengel Z. Rhizosphere properties of Poaceae genotypes under P-limiting conditions. Plant Soil. 2006;283:11-24.

Mateo P, Bonilla I, Fernández-Valiente E, Sanchez-Maeso E. Essentiality of boron for dinitrogen fixation in Anabaena sp. PCC 7119. Plant Physiol. 1986;94:1554-60.

Micallef SA, Channer S, Shiaris MP, Colón-Carmona A. Plant age and genotype impact the progression of bacterial community succession in Arabidopsis rhizosphere. Plant Signaling Behav. 2009;4:777-80.

Mieville A, Granier C, Liousse C, Guillaume B, Mouillot F, Lamarque J-F, Grégoire J-M, Pétron G. Emissions of gases and particles from biomass burning during 20th century using satellite data and an historical reconstruction. Atmos Environ. 2010;44:1469-77.

Mijangos I, Becerril JM, Albizu I, Epelde L, Garbisu C. Effects of glyphosate on rhizosphere soil microbial communities under two different plant compositions by cultivation-dependent and -independent methodologies. Soil Biol Biochem. 2009;41:505-13.

Oberson A, Friesen DK, Rao IM, Bühler S, Frossard E. Phosphorus transformations in an Oxisol under contrasting land-use systems: the role of the soil microbial biomass. Plant Soil. 2001;237:197-210.
Oehl F, Sieverding E, Ineichen K, Mader P, Boller T, Wiemken A. Impact of land use intensity on the species diversity of arbuscular mycorrhizal fungi in agroecosystems of central Europe. Appl Environ Microbiol. 2003;69:2816-24.

Ojima DS, Schimel DS, Parton WJ, Owensby CE. Long- and short-term effects of fire on nitrogen cycling in tallgrass prairie. Biogeochemistry. 1994;24:67-84.

Øvreås L, Forney L, Daae FL, Torsvik V. Distribution of bacterioplankton in meromictic Lake Saelenvannet, as determined by denaturing gradient gel electrophoresis of PCR-amplified gene fragments coding for 16S rRNA. Appl Environ Microbiol. 1997;63:3367-73.

Rachid CTCC, Piccolo MC, Leite DCA, Balieiro FC, Coutinho HLC, Elsas JDV, Peixoto RS, Rosado AS. Physical-chemical and microbiological changes in Cerrado soil under differing sugarcane harvest management systems. BMC Microbiol. 2012;12:170.

Raij B van, Andrade JC, Cantarella H, Quaggio JA. Análise química para avaliação da fertilidade de solos tropicais. Campinas: Instituto Agronômico de Campinas; 2001.

Rao MA, Scelza R, Acevedo F, Diez MC, Gianfreda L. Enzymes as useful tools for environmental purposes. Chemosphere. 2014; 107:145-62.

Resende AS, Xavier RP, Oliveira OC, Urquiaga S, Alves BJR, Boddey RM. Long-term effects of pre-harvest burning and nitrogen and vinasse applications on yield of sugar cane and soil carbon and nitrogen stocks on a plantation in Pernambuco, N.E. Brazil. Plant Soil. 2006;281:339-51.

Ritz K, Mcnicol JW, Nunan N, Grayston S, Millard P, Atkinson D, Gollotte A, Habeshaw D, Boag B, Clegg CD, Griffiths BS, Wheatley RE, Glover LA, Mccaig AE, Prosser JI. Spatial structure in soil chemical and microbiological properties in an upland grassland. FEMS Microbiol Ecol. 2004;49:191-205.

Schnürer J, Clarholm M, Rosswall T. Microbial biomass and activity in an agricultural soil with different organic matter contents. Soil Biol Biochem. 1985;17:611-8.

Schweitzer JA, Bailey JK, Fischer DG, Leroy CJ, Lonsdorf EV, Whitham TG, Hart SC. Plant-soil-microorganism interactions: Heritable relationships between plant genotype and associated soil microorganisms. Ecology. 2008;89:773-81.

Silva FC, organizador. Manual de análises químicas de solos, plantas e fertilizantes. Brasília: Embrapa Comunicação para Transferência de Tecnologia; 1999.

Smalla K, Wachtendorf U, Heuer H, Liu WT, Forney L. Analysis of BIOLOG GN substrate utilization patterns by microbial communities. Appl Environ Microbiol. 1998;64:1220-5.

Smith DN, Inman-Bamber NG, Thorburn PJ. Growth and function of the sugarcane root system. Field Crop Res. 2005;92:169-83.

Smith NR, Kischchuk BE, Mohn WW. Effect of wildfire and harvest disturbances on forest soil bacterial communities. Appl Environ Microbiol. 2008;74:216-24.

Souza RA, Telles TS, Machado W, Hungria M, Guimarães MDF. Effects of sugarcane harvesting with burning on the chemical and microbiological properties of the soil. Agric Ecosyst Environ. 2012;155:1-6.

Stenström J, Svensson K, Johansson M. Reversible transition between active and dormant microbial states in soil. FEMS Microbiol Ecol. 2001;36:93-104. 
Vance ED, Brookes PC, Jenkinson DS. An extraction method for measurement soil microbial biomass-C. Soil Biol Biochem. 1987;19:703-7.

Wallis PD, Haynes RJ, Hunter CH, Morris CD. Effect of land use and management on soil bacterial biodiversity as measured by PCR-DGGE. Appl Soil Ecol. 2010;46:147-50.

Wardle DA. A comparative assessment of factors which influence microbial biomass carbon and nitrogen levels in soil. Biol Rev. 1992;67:321-58.

Wood AW. Management of crop residues following green harvesting of sugarcane in North Queensland. Soil Till Res. 1991;20:69-85.
Wüthrich C, Schaub D, Weber M, Marxer P, Conedera M. Soil respiration and soil microbial biomass after fire in a sweet chestnut forest in southern Switzerland. Catena. 2002;48:201-15.

Yinghua X, Jian S, Qing L, Jing M, Yingwu S, Kai L. Effects of a surface wildfire on soil nutrient and microbial functional diversity in a shrubbery. Acta Ecol Sinica. 2012;32:258-64.

Zak JC, Willig MR, Moorhead DL, Wildman HG. Functional diversity of microbial communities: a quantitative approach. Soil Biol Biochem. 1994;26:1101-8. 